\title{
Tsukumogami emaki and Urban Spaces
}

\author{
SAITŌ Maori
}

Translated by Kristopher ReEveS

sukumogami emaki $i$ 付哼神絵巻 (Illustrated Scroll of Animated Utensils,
$16^{\text {th }}$ century) is a short tale featuring as its protagonists a band of used
utensils who have turned into monsters (yökai 妖怪). This work belongs to a genre of such tales composed between the $14^{\text {th }}$ and $16^{\text {th }}$ centuries, known as otogi-zos shi 御伽草子, or Muromachi tales. More than four hundred of these Muromachi tales exist, a great number of which are accompanied by vivid illustrations. Some have been preserved in the form of books, others in the form of scrolls. In most cases, the author and illustrator, along with the exact date of composition remain uncertain. The author of Tsukumogami emaki, likewise, is yet unknown. In previous research, however, it has been argued that the work shows connections with the illustrated scroll Hyakki yagyo emaki 百鬼夜行絵巻 (Illustrated Scroll of the Parade of Ghouls and Ghosts by Night), as well as with religious ceremonies, such as the Gion Festival 祇園祭, conducted in Kyoto. One of the illustrations in this work contains a quote from another illustrated scroll, namely, Köbō daishi gyōjo emaki 弘法大師行状絵巻 (Illustrated Scroll of the Deeds of Master Kōbō, late $14^{\text {th }}$ century), which points perhaps to the author's interest in Master Kōbō, that is, Kūkai 空海 (774-835), a prominent monk and founder of Shingon 真言, a school of Esoteric Buddhism. Aside from its possible affinity with Buddhism, this illustrated scroll provides important insights into details relating to the convergence and transmission of knowledge, as well as ways in which urban spaces, especially city borders, were once conceived.

The oldest extant manuscript of this scroll, dating back to the Muromachi period, was previously stored in Tō-ji 東寺 temple, Kyoto, and is currently stored in Sōfuku-ji 崇福寺 temple, Gifu. There exist also a number of Edo-period imitations which, despite minor differences in the illustrations, contain more-or-less the same content as the Muromachi manuscript.

Regarding content, a summary of this tale is naturally in order: Sometime in the Kōhō 康保 era (964-968), during the year-end spring cleaning, a number of old utensils are ungratefully discarded. In virtue of their intense sense of indignation, these disgruntled utensils become animated, bent on getting revenge on their human owners. An animated rosary by the name of Ichiren - 連 (literally, "one string," in reference to the string of beads that makes up a rosary) pleads 
with his fellows to renounce their vengeful schemes. This proposal the old utensils promptly refuse, knocking down the rosary without further ado. Thus free to do as they please, the utensils take on their new lively forms, eager to wreak havoc. They set up camp in an area known as Nagasaka 長坂, deep within Mount Funaoka 船岡山, Kyoto, from whence they perpetrate all manner of mischief. In springtime they hold a lavish banquet, in which they conduct religious ceremonies in honor of “the Great God of Shape-shifters" (Henge daimyöin 変化大明神) and give themselves over completely to revelry (Figure 1). In the midst of their raucous celebrating, the utensils chance to bump into a procession of the chancellor and his retinue. Alarmed at the report of these animated utensils, the court decides to conduct prayers aimed at exorcising the malicious creatures. As their only means of escape, the utensils, reconsidering the advice of Ichiren the rosary, decide to take up the life of Buddhist monks. After entering Tō-ji temple, where they dedicate themselves severally to various religious practices, the utensils are at last able to attain enlightenment.

This story begins in the spring and ends in the winter, comprising exactly one full year. The spring and summer scenes are full of life, while the autumn and winter scenes put one in mind of decay, just as one would expect from a work of traditional Japanese literature. Not only this, but the poetry attributed to each of the utensils is also of a fine quality, conforming to traditional literary conventions. The author of this tale was no doubt among the intellectual class. Support for this supposition is to be found in the fact that the Sinitic poems presented by the creatures at the aforementioned banquet all conform to the strict rules of rhyme prescribed of old by Chinese tradition. Our author could not have provided his characters with such verses unless he had himself attained a high degree of erudition in the art.

Of special note here is the presence of an allusion to a tale regarding the Tang-period emperor Xuanzong 玄宗 (Jp. Gensō, 685-762, r. 712-756). Japanese vernacular tales (setsuwa) produced throughout the medieval and early-modern period contain numerous references to this romantic story of Emperor Xuanzong and his most beloved concubine Yang Guifei 楊貴妃 (Jp. Yō Kihi). Tsukumogami emaki was one of many works that utilized this particular tale. Likewise, Japanese monks of the Five Mountains (Gozan 五山) school produced a number of poetry anthologies, such as Shinsenshü 新選集 (Newly Selected Poems) and Kinshüdan 錦紼段 (Brocade of Embroidered Verses), both of which include various examples of Song- and Yuan-period poetry, and both of which contain many allusions to this same tale of Emperor Xuanzong. That these poems bear a close resemblance to those found in Tsukumogami emaki is concrete evidence that the author of the latter work was familiar with Five Mountains poetry. Furthermore, it should be noted that, at the time of our author, the tale of Emperor Xuanzong had become a common subject for painters, such that scenes from this story could be seen on the painted folding screens decorating aristocratic homes. In short, then, the author of Tsukumogami emaki has succeeded in interweaving 


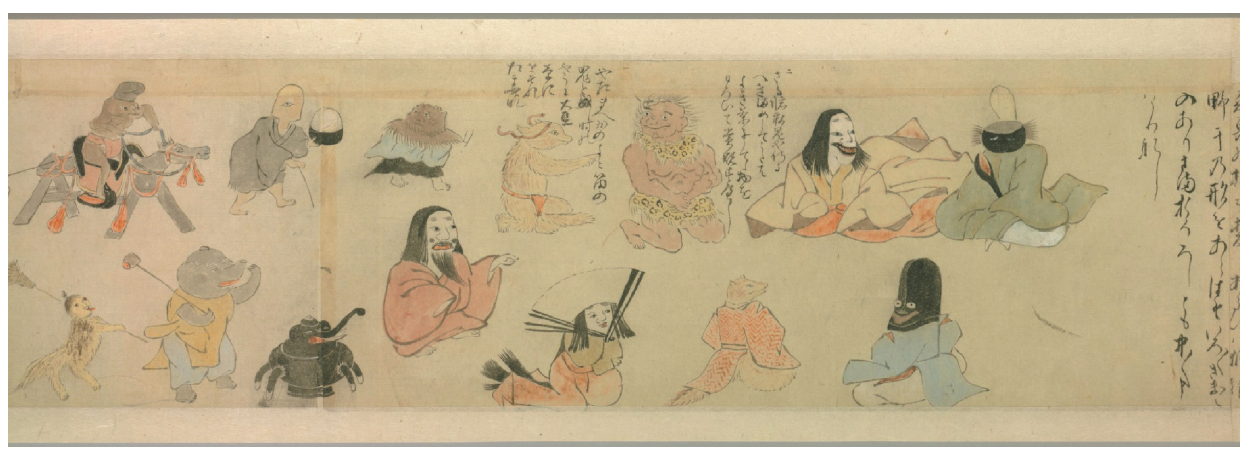

Figure 1. Tsukumogami ki 付喪神記. National Diet Library Manuscript (the original by Tosa Mitsunobu 土佐光信, c.1434-c.1525).

The old utensils are imbued with life. Note the resemblance between the utensils depicted here and the supernatural creatures depicted in the versions of Hyakki yagyo emaki 百鬼夜行絵巻 (Illustrated Scroll of the Parade of Ghouls and Ghosts by Night) housed in the Okura Museum of Art. https://doi.org/10.11501/2541764

elements of high culture, both from the world of visual art as well as that of Five Mountains poetry, into a work that represents an intersection between various strains of cultural understanding.

Of equal interest in terms of actual geographical setting, are the locales depicted in this tale: the utensils set up camp at Nagasaka, deep within Mount Funaoka; they achieved enlightenment in virtue of their association with Tō-ji temple. In the urban world of Kyoto, both of these locales were seen as significant liminal spaces. Mount Funaoka, located in the north of Kyoto, was used throughout the Heian period by the nobility as a scenic place wherein to pick fresh herbs come New Year. On the first Day of the Mouse (according to the Chinese astronomical system), nobles would set out for the foothills about Funaoka with the set purpose of plucking up young pine sprouts. This auspicious event was seen as a means of ensuring longevity, one referenced in many waka verses-as seen, for example, in Tsunenobu shū 経信集 (Collected Poetry of Minamoto no Tsunenobu [1016-1097]) and Fuboku wakashü 夫木和歌抄 (The Fuboku Anthology, c.1310). Despite its vibrant history, however, Mount Funaoka was soon transformed, first, into a cremation ground, as attested by Norinaga shī 教長集 (Collected Poems of Fujiwara no Norinaga, completed sometime after 1178), and then into a ceremonial site wherein solemn rituals for the quelling of epidemics were conducted, as documented in Ryöjin hishō kudensh $\bar{u}$ 梁塵秘抄口伝集 (Oral Transmissions Pertaining to Ryöjin bishō, 1180). In a sense, Mount Funaoka came to embrace both the holy as well as the mundane, both the light as well as the dark aspects of human life.

It must be noted, moreover, that Nagasaka, located as it is behind Mount Funaoka, lies in a more-or-less straight line with Tō-ji temple, which is itself 


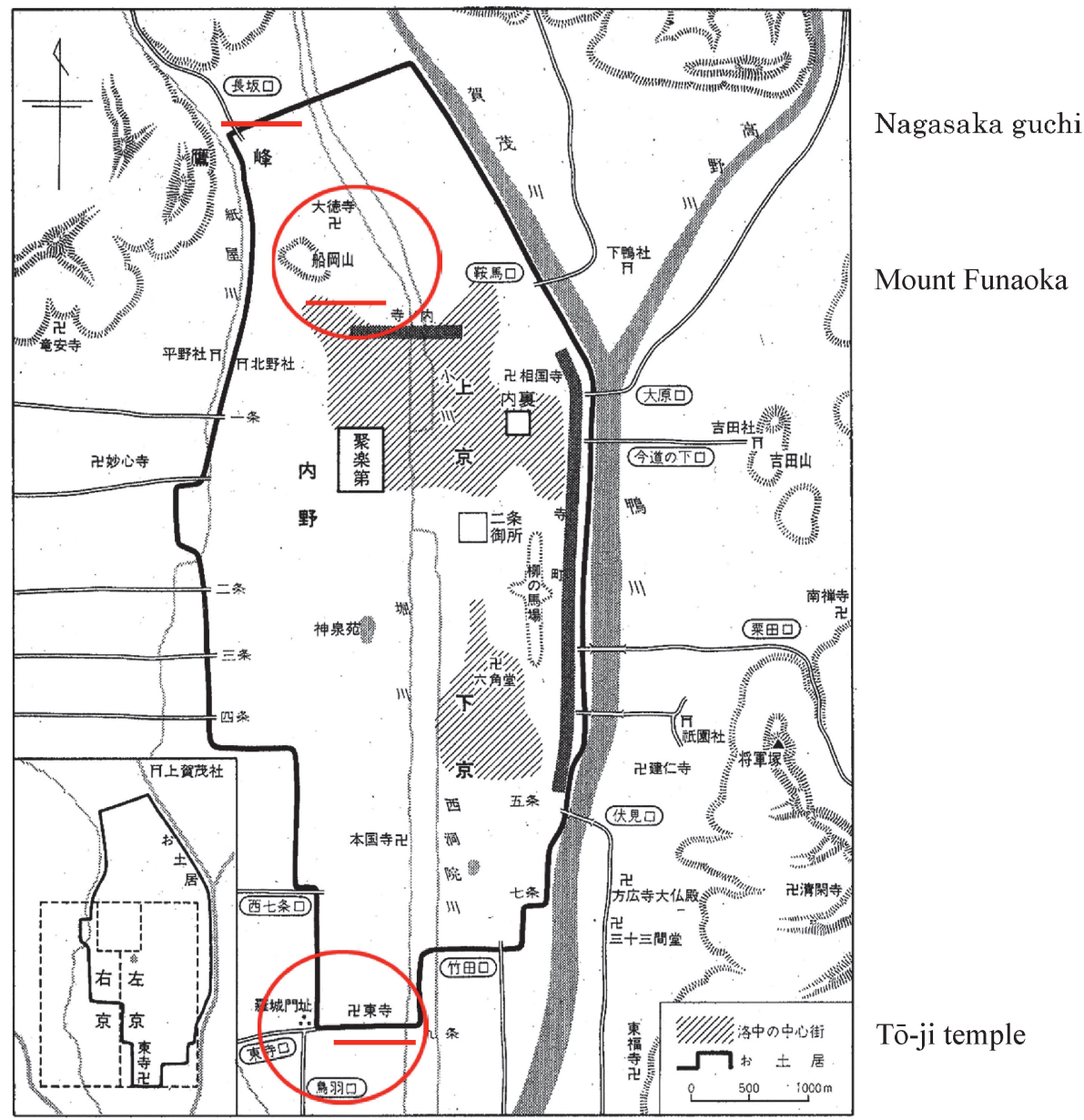

Figure 2. Map of Kyoto. Adapted from Kyōto no rekishi 京都の歴史, vol. 4 (Kyoto: Gakugei Shorin, 1969), p. 296.

Reconstruction of Kyoto in the years Tenshō 天正 18-19 (1590-1591), showing the embankment (odoi j 土居) that once circumscribed the city. Nagasaka, Mount Funaoka, and Tō-ji temple lie along a nearly straight line north to south.

located near the southern extremity of Kyoto. At the beginning of the early modern period, it was customary to speak of the so-called seven doors of Kyoto, gateways leading in and out of the central urban space and the surrounding countryside. Significantly, two of these gateways were known as the Nagasaka Gate (Nagasaka guchi 長坂口), in the north, and the Tō-ji temple Gate (Tō-ji guchi 東寺口), in the south (Figure 2). That these animated utensils are depicted as having dwelt in Nagasaka, on the one hand, and having reached their enlightened end in Tō-ji temple, on the other, speaks to a strong sense of liminality in both of these locales. The utensils move from one liminal space to another, from Nagasaka straight down to Tō-ji temple. Incidentally, the imaginary straight 
line connecting these two locales passes very close to Shinsen'en 神泉苑, a garden just to the south of the imperial compound, where, according to such works as Höbutsushü 宝物集 (Collected Treasures, 1177-1181), apparent nightly sightings of ghouls and ghosts (byakkei yagyo 百鬼夜行) were most frequent. This same line corresponds with what was once, in the very beginning of the Heian period, the main street of the capital, Suzaku Avenue 朱雀大路. This avenue began at Rajōmon Gate 羅城門, the main entrance to the capital, and extended in a straight line to Suzaku Gate 朱雀門, the entrance to the imperial compound. Tō-ji temple was originally erected close by Rajōmon Gate as a means of ensuring the spiritual protection and continual tranquility of the capital. This same Rajōmon Gate is described in various sources, such as Jikkinshō 十訓抄 (A Miscellany of Ten Maxims, preface dated to 1252), as being the haunt of ghouls and ghostsa truly liminal site.

The capital of Kyoto developed in an uneven manner, such that the east side of the city prospered while the west side fell into general disuse. Consequently, Suzaku Avenue very early on ceased to serve as the central thoroughfare, and came, instead, to mark the western boundary of the city. Once one realizes that Suzaku Avenue, at the time Tsukumogami emaki was composed, represented not a bustling avenue, such as, say, Aburakōji 油小路 and others depicted in Gikeiki 義経記 (The Chronicles of Yoshitsune, early $14^{\text {th }}$ century) and Yabyöe nezumi 弥兵衛鼠 (The Adventures of Yahyōe the Mouse, 15-16 $6^{\text {th }}$ century), but rather a little-traveled relic of bygone days, its role in the tale as an eerie footpath for animated utensils at last becomes clear. These utensils wend their way through places formerly, but no longer, frequented by men, places where, depending on the time of day, not a soul is to be found. Such locales, representing as they do a two-fold sort of liminality, both in terms of time as well as space, form the perfect dwelling place, or the perfect road for supernatural creatures, including the rollicking utensils. Tsukumogami emaki is a Muromachi tale which not only displays a rich interweaving of contemporaneous knowledge, but also makes ample use of the liminality of certain urban spaces. ${ }^{1}$

\footnotetext{
${ }^{1}$ For more detailed studies of the issues mentioned in this column, see Saitō Maori 齋藤真麻理, “Yōkai tachi no himitsu kichi: tsukumogami no emaki kara,” 妖怪たちの秘密基地 : 付喪神の絵巻 から, in Ningen bunka 人間文化 27 (2017), pp. 13-18, available online at https://www.nihu.jp/ja/ publication/ningen/27; Saitō Maori, "Muromachi monogatari to Gensō kōtei-e: Tsukumogami emaki wo kiten to shite," 室町物語と玄宗皇帝絵：付喪神絵巻を起点として, in Wakan no kōdo to shizen hyöshö:jüroku-nana seikei no Nihon wo chüshin ni 和漢のコードと自然表象：十六、七世紀の日本 を中心に (Tokyo: Bensei Shuppan, 2020), pp. 240-251.
} 